Supplement of Nat. Hazards Earth Syst. Sci., 20, 2175-2193, 2020

https://doi.org/10.5194/nhess-20-2175-2020-supplement

(c) Author(s) 2020. This work is distributed under

the Creative Commons Attribution 4.0 License.

(c) (1)

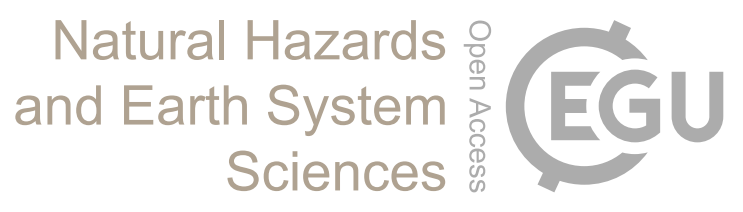

Supplement of

\title{
Anthropogenic climate change and glacier lake outburst flood risk: local and global drivers and responsibilities for the case of lake Palcacocha, Peru
}

Christian Huggel et al.

Correspondence to: Christian Huggel (christian.huggel@geo.uzh.ch)

The copyright of individual parts of the supplement might differ from the CC BY 4.0 License. 
1 Supplementary Material

2

3

4

5

6

7

8

9

10

11

12

In this document further details on the methods applied are provided.

\section{GLOF hazard modeling and analysis}

A glacial lake outburst typically consists of a chain of interacting mass movement processes. Coupled numerical models, simulating the cascade of involved mass movement processes, allow for a quantitative and transparent hazard analysis and mapping of such complex processes (Schneider et al., 2014; Worni et al. 2014). For the analysis of GLOF hazards from lake Palcacocha we here rely on the work presented by Frey et al. (2018) who simulated different GLOF scenarios with numerical mass movement models for three different glacier lakes in the Quillcay catchment, including lake Palcacocha. Their approach follows earlier modeling studies performed at lake Palcacocha by Somos-Valenzuela et al. (2016), and is in line with the recommendations for glacier hazard assessments from the Standing Group on Glacier and Permafrost Hazards in Mountains (GAPHAZ) of the International Association of Cryospheric Sciences and the International Permafrost Association (IACS/IPA) (GAPHAZ, 2017). In the following, the methodological basis of this hazard analysis map is summarized, further details and results can be found in Frey et al. (2018).

For the case of lake Palcacocha, a major ice or combined rock-ice avalanche is considered as the only potential trigger mechanism of a GLOF. Klimeš et al. (2016) showed, that other mass movement processes such as landslides from the inner flanks of the steep Little Ice Age moraines surrounding lake Palcacocha are very unlikely to reach a magnitude which would provoke a major overtopping wave. Considering the structural hazard prevention works, including the reinforced dams and the fixed outlet channel, other critical processes, such as heavy precipitation, seepage and piping in the dam, can as well be excluded as potential GLOF triggers. However, the steep glacierized faces of Mount Palcaraju and Pucaranra have the potential to produce ice avalanches of up to $3 \times 10^{6} \mathrm{~m}^{3}$ in the worst case, which would trigger major impact waves in lake Palcacocha and lead to the overtopping of large volumes of water (cf. Somos-Valenzuela et al., 2016).

Modelled GLOF scenarios for lake Palcacocha are therefore based on a susceptibility analysis for ice and rock-ice avalanches originating from the glaciated headwalls in the surrounding of the lake. Based on an analysis of topography, crevasse patterns and estimated ice thicknesses, following an approach proposed by Schaub et al. (2015), three avalanche scenarios of high, medium and low probability were defined. For each of the three scenarios, the entire chain of mass movement processes was then simulated with corresponding numerical models: Rock-ice avalanches were modeled using the RAMMS model (Christen et al., 2010); impact wave generation and propagation, run up at the dam and overtopping hydrographs were estimated with the hydrodynamic models IBER (IBER, 2010) and FLOW3D (Flow Science, 2012) and cross checked with empirical estimation approaches developed by Heller et al. (2009). Resulting hydrographs of the overtopping waves served as an input for the modelling of the eventual GLOF, which was again conducted using the RAMMS model. These results 
were directly compared to the results from Somos-Valenzuela et al. (2016), obtained with the FLO-2D model. For each scenario, GLOF inundation heights were converted into intensity maps with high and medium intensity if flow height is above or below $1 \mathrm{~m}$, respectively, and eventually translated into hazard levels, according to international and national standards (CENEPRED, 2015; GAPHAZ, 2017; Hürlimann et al. 2006; Raetzo et al., 2002).

A critical point in the process chain described above is the possibility of retrogressive erosion at the dam, which could initiate the formation of a breach in the moraine dam. In this case, much larger volumes of water could be released, leading to an extreme GLOF volume, as it was the case in the 1941 outburst of lake Palcacocha. To assess the susceptibility of the Palcacocha moraine for breach formation, Somos-Valenzuela et al. (2016) applied the BASEMENT model (Vetsch et al., 2018; Worni et al., 2012) for the simulation of erosional processes involved in the formation of a breach. SomosValenzuela et al. (2016) conclude that breach formation at the moraine dam of lake Palcacocha is very unlikely. However, in order to include this unlikely processes as a worst-case scenario, a GLOF resulting from a dam failure at lake Palcacocha was modeled. Resulting affected areas were translated into low hazard level. This corresponds to the Swiss standard of assigning worst-case extreme events with very low probabilities to the lowest (residual) hazard level, irrespective of intensity levels (FOEN, 2016; Schneider et al. 2014), and at the same time fulfills the Peruvian standard of four hazard classes (CENEPRED, 2015).

The hazard map by Frey et al. (2018) represents the GLOF hazard posed by three different lakes in the Quillcay catchment, which also includes lakes Tullparaju and Cuchillacocha in addition to Palcacocha. In turn, the hazard analysis and map shown in Figure 5 represents the GLOF hazard emanating from lake Palcacocha only.

\section{Qualitative research methods on socio-economic risk drivers}

The analysis of socio-cultural and institutional factors incorporates qualitative data gathered during 20 months of ethnographic fieldwork in the Cordillera Blanca between 2017 and 2018. Ethnographic research involves building long-term relationships to gain an in-depth understanding of particular people's ways of life. The co-author Noah Walker-Crawford lived and participated in daily life with farming communities outside of Huaraz and spent extended periods of time following the practices of institutional actors and residents in the city. Research with rural farmers who also live in urban areas designated as dangerous was a particular focus of this study. Information was gathered primarily through informal discussions with informants on their attitudes towards social and environmental change. This data emerged through extended participant observation during which the researcher established relations of trust and gained broader contextual insight into daily life in a changing Andean environment. This involved living with a local family in an Andean village, participating in agricultural work and following government projects to reduce risk from Lake Palcacocha. Gathering information on institutional processes also involved the participation in planning and implementation meetings with 
different governmental and non-governmental institutions. Semi-structured interviews with key informants supplemented data gathered through informal discussions.

Further qualitative evidence comes from the analysis of written materials, both published and unpublished. Archival research was conducted in government and non-governmental archives, where unpublished reports, correspondence, policy briefs, maps, engineering analyses, permits, brochures, pamphlets, and other related materials were collected and analyzed. Newspapers, magazines, and other locally published materials were also consulted in Callejón de Huaylas (Huaraz region) and Lima libraries, newspaper offices, government offices, and company offices. Published sources appearing on the Internet were also consulted, particularly news sources published in Peru in Huaraz and Lima, among other locations. Finally, published scholarship was also consulted and reviewed. In all of these cases, the material was limited in scope and quantity because there is relatively little published about the human dimensions of Lake Palcacocha and few archival, library, or other unpublished sources that discuss the lake or related issues.

\section{References}

CENEPRED (2015). Manual para la Evaluación de Riesgos originados por Fenómenos Naturales. 2nd ed. Lima: Centro Nacional de Estimación, Prevención y Reducción del Riesgo de Desastres (CENEPRED).

Christen, M., Kowalski, J., and Bartelt, P. (2010). RAMMS: Numerical simulation of dense snow avalanches in three-dimensional terrain. Cold Regions Science and Technology 63, 1-14. doi:10.1016/j.coldregions.2010.04.005.

Flow Science (2012): FLOW3D Documentation: Release 10.1.0, Flow Science, Inc., Santa Fe, New Mexico, 811 pp.

FOEN (2016). Protection against Mass Movement Hazards. Guideline for the integrated hazard management of landslides, rockfall and hillslope debris flows. Federal Office for the Environment, Bern. The environment in practice no. 1608: $97 \mathrm{p}$.

Frey, H., Huggel, C., Chisolm, R.E., Baer, P., McArdell, B., Cochachin, A., and Portocarrero, C. (2018). Multi-Source Glacial Lake Outburst Flood Hazard Assessment and Mapping for Huaraz, Cordillera Blanca, Peru. Frontiers in Earth Science 6. doi:10.3189/2015JoG15J017

GAPHAZ (2017). Assessment of Glacier and Permafrost Hazards in Mountain Regions. Eds: S. K. Allen, H. Frey, and C. Huggel, Joint Standing Group on Glacier and Permafrost Hazards in High Mountains (GAPHAZ) of the International Association of Cryospheric Sciences (IACS) and the International Permafrost Association (IPA). Zurich, Lima. Available at: http://gaphaz.org/files/Assessment_Glacier_Permafrost_Hazards_Mountain_Regions.pdf.

Heller, V., Hager, W. H., and Minor, H.-E. (2009). Landslide generated impulse waves in reservoirs. Zurich: Mitteilungen Versuchsanstalt für Wasserbau, Hydrologie und Glaziologie (VAW), ETH Zürich. 
Hürlimann, M., Copons, R., and Altimir, J. (2006). Detailed debris flow hazard assessment in Andorra: A multidisciplinary approach. Geomorphology 78, 359-372. doi:10.1016/j.geomorph.2006.02.003.

IBER (2010). Two-dimensional modeling of free surface shallow water flow, Hydraulic reference manual, IBER v1.0. (www.iberaula.es). (Accessed December 2018)

Klimes, J., Novotný, J., Novotná, I., Urries, B. J., Vilímek, V., Emmer, A., et al. (2016). Landslides in moraines as triggers of glacial lake outburst floods: example from PalcacochaLake (Cordillera Blanca, Peru). Landslides 13, 1461-1477. doi:10.1007/s10346-016-0724-4.

Raetzo, H., Lateltin, O., Bollinger, D., and Tripet, J. (2002). Hazard assessment in Switzerland - Codes of Practice for mass movements. Bull Eng Geol Environ 61, 263-268. doi:10.1007/s10064-002-01634.

Schaub, Y., Huggel, C., and Cochachin, A. (2015). Ice-avalanche scenario elaboration and uncertainty propagation in numerical simulation of rock-/ice-avalanche-induced impact waves at Mount Hualcán and Lake 513, Peru. Landslides. doi:10.1007/s10346-015-0658-2.

Schneider, D., Huggel, C., Cochachin, A., Guillén, S., and García, J. (2014). Mapping hazards from glacier lake outburst floods based on modelling of process cascades at Lake 513, Carhuaz, Peru. Adv. Geosci. 35, 145-155. doi:10.5194/adgeo-35-145-2014.

Somos-Valenzuela, M. A., Chisolm, R. E., Rivas, D. S., Portocarrero, C., and McKinney, D. C. (2016). Modeling a glacial lake outburst flood process chain: the case of Lake Palcacocha and Huaraz, Peru. Hydrology and Earth System Sciences 20, 2519-2543. doi:10.5194/hess-20-2519-2016.

Vetsch, D., Siviglia, A., Caponi, F., Ehrbar, D., Gerke, E., Kammerer, S., et al. (2018). System Manuals of BASEMENT. Zurich: Laboratory of Hydraulics, Glaciology and Hydrology (VAW). ETH Zurich. Available at: http://www.basement.ethz.ch. (Accessed December 2018)

Worni, R., Huggel, C., Clague, J. J., Schaub, Y., and Stoffel, M. (2014). Coupling glacial lake impact, dam breach, and flood processes: A modeling perspective. Geomorphology 224, 161-176. doi:10.1016/j.geomorph.2014.06.031.

Worni, R., Stoffel, M., Huggel, C., Volz, C., Casteller, A., and Luckman, B. (2012). Analysis and dynamic modeling of a moraine failure and glacier lake outburst flood at Ventisquero Negro, Patagonian Andes (Argentina). Journal of Hydrology 444-445, 134-145. doi:10.1016/j.jhydrol.2012.04.013. 